\title{
УДК 658.512.4
}

JEL classification O22, D81, G32

DOI: https://doi.org/10.35774/visnyk2020.02.174

\author{
Петро МИкИтюк, \\ доктор економічних наук, професор, \\ професор кафедри менеджменту, публічного управління та персоналу \\ Тернопільський національний економічний університет, \\ вул. Львівська, 11, м. Тернопіль, Україна, 46009 \\ e-mail: pp.mykytiuk@gmail.com \\ ORCID ID: 0000-0002-3038-6886
}

\author{
Алла КАСИЧ, \\ доктор економічних наук, професор, \\ завідувач кафедри менеджменту та публічного адміністрування \\ Київський національний університет технологій та дизайну, \\ м. Київ, Україна, \\ e-mail: kasich.alla@gmail.com \\ ORCID ID: 0000-0001-7019-1541
}

\section{СУЧАСНІ МЕХАНІЗМИ РОЗВИТКУ ІННОВАЦІЙ В БУДІВЕЛЬНІЙ ГАЛУЗІ}

Микитюк П., Касич А. Сучасні механізми розвитку інновацій в будівельній галузі. Вісник Тернопільського національного економічного університету. 2020. Вип. 2. С. 174-184. DOI: https://doi.org/10.35774/visnyk2020.02.174

Mykytyuk P., Kasych A. (2020). Suchasni mekhanizmy rozvytku innovatsii v budivelnii haluzi [The modern mechanisms for the development of innovations in the construction industry]. The Herald of Ternopil National Economic University, Vol. 2. P. 174-184. DOI: https://doi.org/10.35774/visnyk2020.02.174

\section{Анотація}

Вступ. У статmі на основі дослідження сучасного українського і міжнародного досвіду в сфрері інновацій в житловому будівництві проаналізовано існуючі бар'єри i специфіку розвитку будівельної галузі, розкрито та обгрунтовано основні можливості і перспективні напрямки програмно-цільової підтримки організаційноекономічних і управлінських інновацій з метою підвищення доступності та можливості поліпшення новозбудованого житла для громадян, мінімізації комунальних витрат населення, переходу до нових технологій будівництва житла з низькими витратами на його експлуатацію. Запропоновано конкретні напрямки для державних і регіональних органів влади щодо підвищення інвестиційної

(C) Петро Микитюк, Алла Касич 2020. 
привабливості інноваційного житлового будівництва $і$ переходу галузі на інноваційний вектор розвитку.

Мета дослідження полягає в розгляді сучасних механізмів розвитку інновацій в будівельній галузі.

Meтоди дослідження. В процесі розробки й обгрунтування результатів дослідження активно використовувалися такі методи дослідження: аналіз, синтез, моделювання, логічний, системний підхід, методи дедукції та індукції, а також спостереження, вимірювання, порівняння, експеримент.

Результати. Виявлено залежність розвитку будівельної галузі з розвитком суміжних галузей, рівнем зайнятості населення. Також було визначено, що для успішного розвитку галузі повинні бути створені відповідні умови для підвищення інвестиційної привабливості інноваційного житлового будівництва. Також були виділені основні бар'єри розвитку інноваційного житлового будівництва в Україні.

Перспективи. Перспективи подальшого розвитку дослідження полягають в удосконаленні нормативно-правового стимулювання розвитку галузей матеріального виробництва, стимулювання процесів переходу на нові технології зведення житла, розвитку процесів використання передових автоматизованих систем проектування та управління будівлями на основі ВІМ-технологій та розвиток інституту орендного житла в рамках концесійних угод з інвесторами.

Ключові слова: інвестиційна привабливість інновацій, програмно-цільовий розвиток інноваційного житлового будівництва, житлова політика, механізми підтримки інновацій, організаційно-економічні та управлінські інновації.

Формули: 0, рис.: 2, табл.: 1, бібл.: 10.

\section{Abstract}

\section{Petro MYKYTYUK, Alla KASYCH}

\section{THE MODERN MECHANISMS FOR THE DEVELOPMENT OF INNOVATIONS IN THE CONSTRUCTION INDUSTRY}

Introduction. In the article, based on research of modern Ukrainian and international experience in the field of improvement of mechanisms of development of innovations in the field of housing, the existing barriers and specifics of the development of the industry are analyzed, the main opportunities and perspective directions of program-target support of organizational-economic and managerial innovations are opened with the purpose of increasing accessibility and opportunities for improving the living conditions of citizens, minimizing public utility costs, switching to low-cost housing for yoga operation. Specific directions for state and regional authorities to increase the investment attractiveness of innovative housing construction and the transition of the industry to the innovative vector of development are proposed.

The purpose of the study is to consider modern mechanisms for the development of innovations in the construction industry.

Results. The dependence of the development of the construction industry with the development of related industries, the level of employment is revealed. It was also determined that for the successful development of the industry, appropriate conditions 
must be created to increase the investment attractiveness of innovative housing. The main barriers to the development of innovative housingin Ukraine were also identified.

Discussion. Prospects for further development of the study are to improve regulatory and legal incentives for the development of material production, stimulate the transition to new technologies of housing, development of advanced automated systems for design and management of buildings based on BIM-technologies and development of rental housing under concession agreements with investors.

Keywords: investment attractiveness of innovations, programmatic development of innovative housing construction, housing policy, mechanisms of support of innovations, organizational-economic and managerial innovations.

Formulas: 0, fig.: 2, tab.: 1, bibl.: 10.

Постановка проблеми. Сучасний стан будівельної галузі України обумовлений нестабільністю фрінансового ринку, а також реальним зниженням доходів населення. Одним 3 актуальних питань стає пошук нових механізмів економічного розвитку країни і вдосконалення заходів соціальної підтримки населення, також створення умов для підвищення інвестиційної привабливості інноваційного житлового будівництва. При цьому найбільш ефективним видається запуск заходів програмноцільової підтримки зазначеного напрямку з метою збалансованого розвитку регіонів, створення привабливих умов для інвестування в житлові інновації та вирішення загальнодержавних завдань щодо забезпечення громадян комфортним і доступним житлом.

Аналіз останніх досліджень і публікацій. Вивченню сутності інновацій та їх прикладного застосування в будівельній галузі присвячена велика кількість праць як зарубіжних, так і українських вчених, серед яких можна виділити А. В. Радкевич, Ю. І. Микитюк, Ю. В. Коротаєву, Т. Л. Керанчук, Г. Павловські, Л. В. Проданову, О. П. Бубенко і ряд інших дослідників. Проте в їх працях не було повною мірою відображено питання впровадження механізмів розвитку інновацій в будівельних організаціях.

Метою статті $€$ розгляд сучасних механізмів розвитку інновацій в будівельній галузі.

Виклад основного матеріалу. В період невизначеності та нестабільності економічної ситуації в Україні одним із значущих напрямків, що повинні просуватися державними та регіональними органами влади, $є$ розробка заходів з покращення житлових умов громадян.

В даний час підтримка житлового будівництва є перспективним напрямком, здатна робити мультиплікативний ефект у розвитку супутніх галузей. Це зумовлено тим фактом, що в тому чи іншому вигляді сприяння розвитку зазначеної галузі забезпечує більше 4\% працездатного населення країни, при цьому в самій галузі застосовуються тисячі різних матеріалів, виробів, послуг, що є результатом функціонування більше десяти галузей національної економіки: від кредитно-фінансової сфери до низки галузей матеріального виробництва (рис. 1). Крім того, ефеективне функціонування будівельної галузі сприяє планомірному оздоровленню ринку праці. Так, за оцінками експертів, діяльність одного робітника в будівельній індустрії забезпечується 
результатами десяти робітників з супутніх будівництву галузей національної економіки. Зазначені обставини характеризують високий ступінь впливу галузі в цілому на успішність соціально-економічного розвитку країни. 3 урахуванням зазначених обставин одним з перспективних напрямків $€$ пошук шляхів щодо вдосконалення механізмів підтримки та розвитку будівельної галузі.

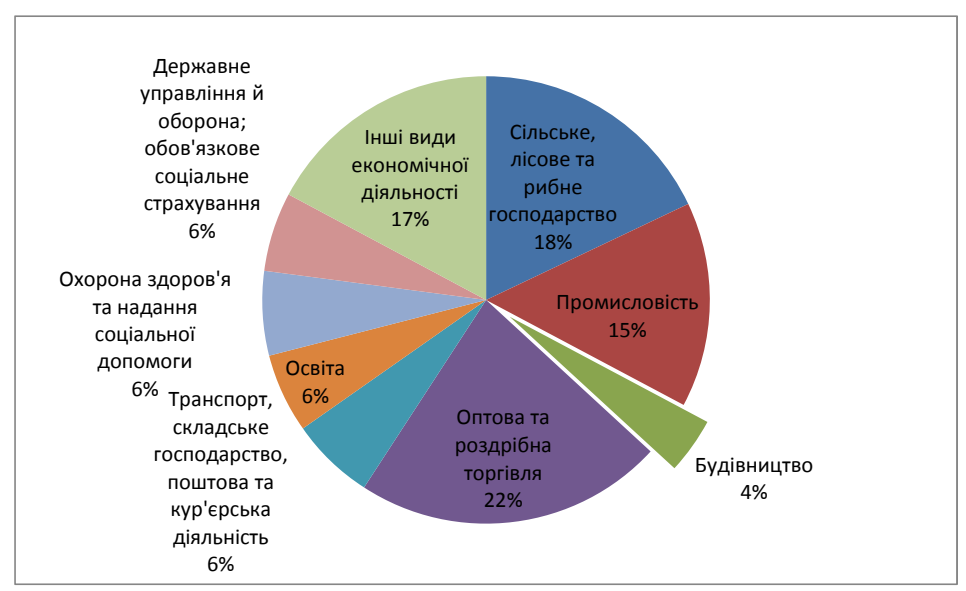

Рис 1. Галузева структура зайнятості населення на 2018 рік [1]

На нашу думку, одним з перспективних напрямків соціально-економічного розвитку країни є створення умов для підвищення інвестиційної привабливості інноваційного житлового будівництва. При цьому найбільш ефективним видається запуск заходів програмно-цільової підтримки зазначеного напрямку 3 метою збалансованого розвитку регіонів, створення привабливих умов для інвестування в житлові інновації та вирішення загальнодержавних завдань щодо забезпечення громадян комфортним і доступним житлом[2].

Програмно-цільовий підхід розвитку інноваційного житлового будівництва повинен базуватися на просуванні нових фрорм управлінських, організаційно-економічних і технологічних інновацій.

На основі аналізу праць вітчизняних та зарубіжних науковців і беручи до уваги тематику статті, під інноваціями будемо розуміти впровадження нових або вдосконалення існуючих фрорм управлінських, організаційно-економічних і технологічних нововведень в будівельній галузі, які забезпечують впровадження досягнутих результатів в практичну діяльність суб'єктів управління і фрункціонування галузі для підвищення її ефективності та досягнення позитивного соціальноекономічного ефекту[3].

У свою чергу дослідження існуючих головних аспектів інноваційного будівництва [4] дозволяють виділити наступні барлєри його розвитку в Україні:

- недосконалість законодавства в галузі земельних відносин, тривалі терміни і висока вартість отримання початково-дозвільних узгоджень на зведення житла;

- високі процентні ставки кредитів на розвиток інноваційного будівництва і як результат недостатня привабливість для учасників галузі фрінансування інноваційних розробок і їх комерціалізації; 
- складність сертифрікації та виведення на ринок нових інноваційних матеріалів і технологій на тлі низької якості будівельних матеріалів і проектування на основі застарілих будівельних стандартів;

- брак необхідних обігових коштів на модернізацію обладнання та основних фондів підприємств;

- недостатній державний контроль над виникаючими ризиками в сфері ціноутворення на сировину і енергоносії, необхідні для інноваційного будівництва;

- слабкі заходи підтримки і залучення забудовників, в тому числі і іноземних, які мають досвід застосування інновацій в житловому будівництві;

- відсутність на державному і регіональних рівнях єдиного портфеля привабливих для інвестора замовлень в сфері інноваційного розвитку територій;

- недостача, а й деколи відсутність енергетичних і інфраструктурних потужностей для розвитку віддалених від центрів територій;

- слабка державна підтримка просування організаційно-управлінських нововведень та перспективних технологій на різних етапах будівництва та експлуатації об'єктів нерухомого майна;

- наявність роз'єднаних методик з аналізу привабливості реалізації інноваційних будівельних проектів.

На основі викладеного пропонується класифікувати зазначені негативні барґєри, що перешкоджають розвитку інновацій в будівництві, на наступні фактори: законодавчі, організаційно-управлінські, методико-інформаційні (таблиця 1).

Зазначені барєєри, поряд 3 іншими, дозволяють охарактеризувати будівельну галузь як консервативну.

У зв'язку з цим, для подолання визначених бар'єрів потрібно вдосконалювати загальнодержавну політику в сфері інноваційного житлового будівництва за допомогою забезпечення мотивуючих умов (податкові та інші пільги, субсидії, методична, інформаційна та організаційна підтримка) для перебудови системи відносин суб'єктів галузі на інноваційний вектор розвитку. Крім того, одним з важливих аспектів на даному напрямку стає вдосконалення законодавства і запуск відповідних цільових програм зі створення стимулів для формування основи у всіх учасників галузі та активному переходу на розвиток і комерціалізацію перспективних ідей і технологічних рішень. На нашу думку, успішне вирішення поставлених стратегічних завдань можливе за допомогою програмно-цільового підходу [5].

Таблиця 1

Негативні фактори розвитку інновацій в будівництві

\begin{tabular}{|c|c|c|}
\hline \multicolumn{3}{|c|}{ Фактори } \\
\hline методико-інформаційні & законодавчі & організаційно управлінські \\
\hline $\begin{array}{c}\text { Відсутність загальноприйнятої } \\
\text { методики оцінки ризиків при } \\
\text { застосуванні та реалізації } \\
\text { інновацій в житловому } \\
\text { будівництві }\end{array}$ & $\begin{array}{c}\text { Недостатня кількість цільових } \\
\text { програм і законодавчих } \\
\text { актів щодо стимулювання } \\
\text { розробки та впровадження } \\
\text { організаційних, управлінських } \\
\text { і технологічних інновацій в } \\
\text { житлове будівництво }\end{array}$ & $\begin{array}{c}\text { Недостатнє нормативно- } \\
\text { правове стимулювання } \\
\text { процесів організації взаємодії } \\
\text { наукових і будівельних } \\
\text { організацій з метою } \\
\text { впровадження інноваційних } \\
\text { ідей та рішень в організацію } \\
\text { і управління інноваційним } \\
\text { будівництвом }\end{array}$ \\
\hline
\end{tabular}




\begin{tabular}{|c|c|c|}
\hline & & продовження таблиці 1 \\
\hline $\begin{array}{c}\text { Відсутність сформованої } \\
\text { субкультури і соціального } \\
\text { замовлення на повсюдне } \\
\text { впровадження організаційно- } \\
\text { управлінських і будівельних } \\
\text { інновацій в рамках зведення і } \\
\text { експлуатації житла }\end{array}$ & $\begin{array}{c}\text { Тривалі законодавчі } \\
\text { процедури щодо практичної } \\
\text { комерціалізації винайденої } \\
\text { інноваційної продукції, } \\
\text { технологій і запропонованих } \\
\text { ідей на тлі недосконалості } \\
\text { системи сертифікації }\end{array}$ & $\begin{array}{c}\text { Складні і тривалі механізми } \\
\text { сертифікації і просування } \\
\text { на ринок нової продукції і } \\
\text { технологій на фоні відсутності } \\
\text { сприятливого клімату щодо } \\
\text { інвестування в розробку і } \\
\text { комерціалізацію інноваційних } \\
\text { ідей та рішень }\end{array}$ \\
\hline $\begin{array}{c}\text { Недостатня інформованість } \\
\text { суспільства в області якості } \\
\text { інноваційного будівництва і } \\
\text { можливості мінімізації витрат } \\
\text { в процесі експлуатації, що } \\
\text { формує консервативний } \\
\text { настрій при покупці житла }\end{array}$ & $\begin{array}{c}\text { Недосконалість законодавства } \\
\text { в сфрері підтримки автономного } \\
\text { і дохідного житлового } \\
\text { будівництва на основі } \\
\text { енергозберігаючих технологій } \\
\text { та альтернативної енергетики }\end{array}$ & $\begin{array}{c}\text { Монополія великих } \\
\text { регіональних будівельних } \\
\text { компаній, які отримують } \\
\text { найкращі умови для } \\
\text { будівництва і незацікавлених у } \\
\text { вкладенні коштів в інноваційні } \\
\text { житлові проекти. }\end{array}$ \\
\hline $\begin{array}{c}\text { Потреба в розробці } \\
\text { науково-обґрунтованих } \\
\text { методик оцінки результату } \\
\text { і економічної ефективності } \\
\text { від застосування конкретних } \\
\text { інноваційних ідей та рішень }\end{array}$ & $\begin{array}{c}\text { Брак державних і регіональних } \\
\text { програм субсидування та } \\
\text { надання пільг інвесторам } \\
\text { при комплексному розвитку } \\
\text { територій в рамках } \\
\text { інноваційного будівництва }\end{array}$ & $\begin{array}{c}\text { Відсутність єдиного } \\
\text { визначення мети у суб’єктів } \\
\text { галузі в ході розвитку } \\
\text { комплексних проектів } \\
\text { під інноваційне житлове } \\
\text { будівництво, на тлі низької } \\
\text { якості їх обґрунтування } \\
\text { для залучення венчурних } \\
\text { інвесторів } \\
\end{array}$ \\
\hline $\begin{array}{c}\text { відсутність єдиного } \\
\text { загальноукраїнського реєстру } \\
\text { з майданчиками і типовими } \\
\text { інноваційними проектами } \\
\text { для венчурного інвестування } \\
\text { і комплексного житлового } \\
\text { розвитку будівельними } \\
\text { організаціями }\end{array}$ & $\begin{array}{c}\text { Неефективні законодавчі } \\
\text { механізми щодо } \\
\text { адміністрування інноваційних } \\
\text { будівельних процесів з } \\
\text { урахуванням інфляційних } \\
\text { ризиків і істотній залежності } \\
\text { від зовнішніх чинників }\end{array}$ & $\begin{array}{c}\text { Недосконалість методик і } \\
\text { механізмів обліку та розподілу } \\
\text { ризиків в рамках концесійних } \\
\text { угод та інших фоорм державно- } \\
\text { приватного партнерства }\end{array}$ \\
\hline $\begin{array}{c}\text { Недостатньо розвинені } \\
\text { технології інформаційного } \\
\text { моделювання та управління } \\
\text { житловими будинками на } \\
\text { всіх етапах їх зведення і } \\
\text { експлуатації }\end{array}$ & $\begin{array}{c}\text { Наявність бар'єрів з боку } \\
\text { страхових і кредитно- } \\
\text { фінансових установ щодо } \\
\text { виділення коштів на } \\
\text { інноваційні будівельні проекти }\end{array}$ & $\begin{array}{c}\text { Роз'єднаність повноважень } \\
\text { в сорері розробки і } \\
\text { впровадження інновацій } \\
\text { на тлі потреби в створенні } \\
\text { єдиного інтегратора розвитку } \\
\text { інноваційних ідей і конкретних } \\
\text { технологічних рішень }\end{array}$ \\
\hline
\end{tabular}

3 урахуванням викладеного, а також на основі проведеного аналізу останніх зарубіжних і вітчизняних досягнень у зазначеній сфері [6] необхідно виділити наступні перспективні напрямки розвитку будівельних інновацій:

1. Нормативно-правове стимулювання розвитку галузей матеріального виробництва, що спеціалізуються на створенні нових енергозберігаючих та енерговиробляючих будівельних матеріалів і технологій, шляхом надання різних пільг в рамках програмно-цільового підходу та державного субсидування.

2. Стимулювання процесів переходу на нові технології зведення житла, в тому числі за допомогою 3D-друку і застосування взаємозамінних модульних конструкцій з внутрішніми отворами для проведення комунікацій без порушення конструктиву 
будівлі при його обслуговуванні, для збільшення швидкості будівництва, а також можливості заміни окремого модуля (квартири) [7].

3. Розвиток процесів використання передових автоматизованих систем проектування та управління будівлями на основі ВІМ-технологій, що забезпечують можливості для всіх сублєктів будівництва з моделювання, конструювання та колективного використання інформаційної моделі житлових будинків на протязі всього життєвого циклу (рисунок 2).

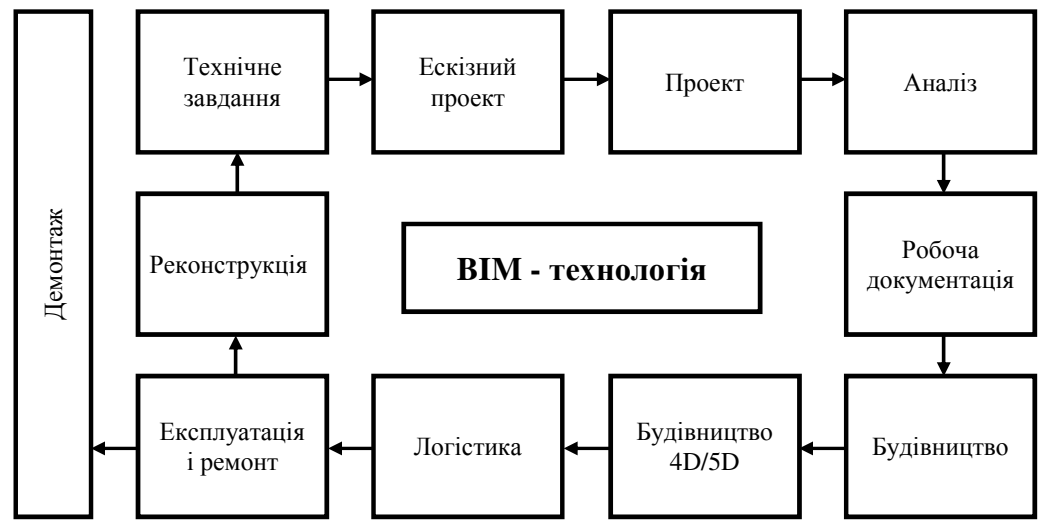

Рис 2. ВІМ-технології управління життєвим циклом житлових будинків [8]

4. Нормативно-правове стимулювання будівельних компаній щодо збільшення меж фінансування інноваційних науково-дослідних розробок в інтересах будівельної галузі для їх подальшої комерціалізації і впровадження в рамках будівельних, управлінських і організаційних процесів.

5. Створення, в рамках відповідної цільової програми, інституту будівництва автономної інфраструктури та житла 3 метою скорочення загальнодержавних витрат на проведення та обслуговування центральних комунікацій, а також витрат громадян на утримання житла. Даний напрямок так само дозволить за допомогою застосування останніх досягнень в галузі відновлюваної енергетики (використання енергії сонця, вітру, землі, газифікація шляхом переробки біомаси тощо) підвищити ефективність енергопостачання і розвитку віддалених від обласних центрів районів, а також поліпшити екологічну ситуацію. Для цих цілей потрібна розробка відповідних державних цільових програм, що створюють різні стимулюючі форми підтримки і розвитку автономного житлового будівництва як в рамках окремих приватних будівель, так і мікрорайонів.

6. Розвиток інституту орендного житла в рамках концесійних угод з інвесторами. Зазначений напрямок буде сприяти поліпшенню житлових умов громадян, а також забезпечить можливість органам влади на місцях формувати міжрегіональні трудові міграційні потоки. При цьому концесіонери для скорочення витрат на утримання подібного роду житла будуть зацікавлені в застосуванні інноваційних технологій при його будівництві та експлуатації, забезпечуючи тим самим підтримку ринку розвитку будівельних інновацій. 
7. Створення єдиної державної інформаційної системи для дистанційної подачі, обробки, узгодження і видачі всіх необхідних початково-дозвільних документів.

8. Формування інституту інновацій, як єдиної державної структури, яка забезпечує координацію зусиль для підтримки і практичної реалізації інноваційних ідей та рішень в різних галузях національної економіки, в тому числі і будівельної.

Безумовно, підтримка і стимулювання розвитку зазначених та інших перспективних напрямків інноваційного будівництва повинні здійснюватися в рамках розробки відповідних державних програм, що передбачає необхідність створення стратегії і дієвих механізмів розвитку галузі [9]:

1. Створення сприятливого інвестиційного клімату щодо фрінансування проектів будівництва інноваційного житла. Пропонується доповнити відповідні нормативноправові акти нормами, що надають податкові, майнові, земельні пільги і відрахування, а також пільгові позики та застосування норм прискореної амортизації для інвесторів, забудовників, виробників, що забезпечують розробку і впровадження інноваційної продукції на рівнях не нижче затверджених органами влади. При цьому безпосередній обсяг реалізації відповідних інновацій пропонується розділити на кілька рівнів: базовий, середній, високий, виходячи з якого встановлювати розмір відповідних пільг для суб'єктів будівельної галузі. Зазначені умови забезпечать прагнення учасників ринку постійно покращувати вироблені товари і послуги, тим самим фрормуючи перехід на інноваційний вектор розвитку як будівельної індустрії, так і супутніх галузей.

2. 3 метою підвищення якості адміністрування процесів з боку органів влади пропонується створення уніфікованої загальноукраїнської інформаційної системи на основі ВІМ-технологій, яка повинна забезпечити віддалене надання всієї сукупності державних послуг і акумулювання інформаційної моделі житлового будинку, починаючи від початкової стадії до етапів його експлуатації та демонтажу.

3. Створення на базі державних будівельних структур інституту інновацій для координації і консолідації взаємодії між суб'єктами ринку, в тому числі для мінімізації бар'єрів комерціалізації інновацій, спрощення і прискорення процедур сертифікації та виведення на ринок нової продукції, підтримки інновацій. На утворену структуру пропонується покласти обов'язки щодо вдосконалення законодавчих актів, зокрема різних сертифікацій, патентування, стандартів з урахуванням останніх досягнень в сфері науки і техніки, а також розробку механізмів стимулювання їх впровадження в будівельну та супутні галузі. Крім того, зазначена структура повинна нести відповідальність за формування реєстру інноваційних проектів в регіонах України на довгострокову перспективу для зацікавлених в цьому інвесторів і девелоперів.

Необхідно також здійснити організацію банку будівельних інновацій, де в онлайн режимі будуть представлені найбільш ефективні рішення в сфері інноваційного будівництва і супутніх технологій. Крім того, необхідно організувати відбір найбільш вдалих з них, які набрали найбільшу кількість голосів громадян, для подальшої інвестиційної підтримки в рамках відповідних державних і регіональних програм.

4. Розробити державну цільову програму з підтримки і розвитку в регіонах України автономного житлового будівництва на основі останніх досягнень в галузі альтернативної енергетики. Зазначені умови дозволять надати додатковий імпульс розвитку віддалених територій, які вважалися раніше неперспективними з причини 
відсутності необхідних комунікацій, знизити державні витрати на прокладку центральних комунікацій і втрати від їх експлуатації, а також забезпечать зниження шкоди екології від життєдіяльності суспільства. На початковому етапі вказане нововведення ефективніше реалізовувати в рамках будівництва мікрорайонів індустріального малоповерхового типу забудови (до 4 поверхів). В подальшому після апробації технічних ідей і рішень, можливий перехід на багатоповерхове автономне будівництво.

5. Розробка і реалізація на практиці програми з надання пільгових умов для кредитно-фрінансових організацій, що видають відповідні цільові позики на розвиток інноваційного будівництва і виробництва необхідних інноваційних матеріалів. Рівні наданих державою пільг також пропонується розділити за ступенем інноваційності проекту. За надання позик на проекти з великим рівнем ефективних нововведень передбачити кращі пільгові умови кредитування від держави.

6. Впровадження державних і регіональних програм щодо пільгових умов в рамках концесійних угод для інвесторів і девелоперів, які здійснюють комплексний розвиток територій під інноваційну житлову забудову.

7. Удосконалення підтримки інноваторів і науково-дослідних структур, а також їх взаємодії з безпосередніми виробниками за допомогою надання цільових грантів на розробку та впровадження інноваційних ідей, методик і конкретних організаційнотехнологічних рішень, забезпечення захисту авторських прав на інтелектуальну власність, стимулювання підготовки інноваційно-мислячих співробітників, здатних забезпечити зменшення собівартості та енергоємності для створення одиниці продукції (послуги, операції). Зокрема, аналіз іноземного досвіду інноваційного житлового будівництва дозволяє стверджувати про тенденції переходу на проектування та будівництво житлових будинків з урахуванням енергоспоживання не більше 20 кВтгод/рік на квадратний метр.

8. Формування у населення потреби в пошуку шляхів покращення умов життєдіяльності та прийняття інновацій за допомогою інформування про отримання відповідних пільг і зниження витрат при впровадженні того чи іншого інноваційного будівельного товару і послуги [10].

Висновки та перспективи подальших досліджень. Успішним прикладом розвитку будівельної галузі було б законодавче стимулювання процесів державноприватного партнерства в формі концесійних угод і договорів про комплексний розвиток територій під житлову забудову. Розробка і запуск відповідних державних цільових програм стали б якимось драйвером переходу на інноваційний вектор розвитку і комерціалізації, як перспективних технологічних ідей і рішень, так і впровадження запропонованих організаційно-управлінських нововведень, в тому числі інноваційного адміністрування процесів на всіх етапах життєвого циклу будівництва.

Незважаючи на певну кризу в будівельній галузі, питання розвитку гостро стоїть на порядку денному, тому подальше дослідження даних питань є перспективним. Зараз перед урядом стоїть необхідність внести деякі корективи і поправки в законодавство, посилити державний вплив і регулювання даної галузі. Так як ринок знаходиться в прямій залежності від ринку житлового будівництва, слід активізувати розвиток саме цього напрямку, що дозволить розширити обсяг будівельних робіт, а також вирішити 
безліч соціальних проблем, що стосуються забезпечення людей безпечним і доступним житлом. Безумовно, цілеспрямована державна підтримка розвитку будівельної галузі на основі запропонованих нововведень створить базис для мультиплікативного ефекту як в будівництві, так і суміжних галузях, що в підсумку дасть справедливу розв'язку стратегічних соціально-економічних завдань держави.

\section{תimepamypa}

1. Зайняте населення за видами економічної діяльності у 2012-2018 роках. URL: http://www.ukrstat.gov.ua/operativ/operativ2014/rp/zn_ed/zn_ed_u/zn_ed_2013_u. htm

2. Микитюк Ю. І. Управління портфелем інноваційно-інвестиційних проектів у житловому будівництві. Вісник Тернопільського національного економічного університету. 2019. Вип. 1. С. 151-159. URL : http://dspace.tneu.edu.ua/ handle/316497/34045 (дата звернення 02.03.2020).

3. Радкевич А. В., Арутюнян І. А., Сайков Д. В. Оптимізація організаційних процесів будівельного виробництва як формотворча складова конкурентоспроможності підрядних підприємств. Шляхи підвищення ефективності будівництва в умовах фрормування ринкових відносин: зб. наук. праць. Вип. 35. К.: Вид-во Ліра-К, 2018. С. 64-73.

4. Коротаєва Ю. В. Формування та використання потенціалу будівельної галузі. Держава та регіони. Серія: Економіка та підприємництво. 2017. № 3. С. 1519.

5. Павловські Г. Щодо проблем розвитку діяльності підприємств будівельної сорери в Україні. Міжнародний науковий журнал «Інтернаука». 2017. № 3 (2). С. 124-135.

6. Проданова Л. В., Панкова Л. І., Зайва Ю. О. Проблемні аспекти розвитку ринку будівельної галузі України. Економічний вісник Запорізької державної інженерної академії. 2016. Вип. 6 (2). С. 57-61.

7. Микитюк П. П. Інвестиційно-інноваційний менеджмент : навч. посіб. Тернопіль : Економічна думка, 2015. 452 с.

8. Керанчук Т. Л. Концепція вартісно-орієнтованого управління підприємством та можливості її адаптації в Україні. Фінанси України. 2011. № 7. С. 104-114.

9. Бубенко О. П. Інноваційні складові підвищення ефективності будівельних підприємств. Бізнес/нформ. 2012. № 12. С. 156-161.

10. Китайські проекти Зд будинків. URL : https://tjournal.ru/53763-villas-createdusing-3d-printers.

\section{References}

1. Zainyate naselennia za vydamy ekonomichnoyi diialnosti u 2012-2018 rokah (2014). Retrieved from : http://www.ukrstat.gov.ua/operativ/operativ2014/rp/zn_ed/ zn_ed_u/zn_ed_2013_u.htm [in Ukrainian].

2. Mykytiuk, Yu. I. (2019) Upravlinnia portfelem innovatsiino-investytsiinykh proektiv u zhytlovomu budivnytstvi [Management of a portfolio of innovation and 
investment projects in housing construction]. Visnyk Ternopilskoho natsionalnoho ekonomichnoho universytetu. №. 1. P. 151-159. Retrieved from http://dspace.tneu. edu.ua/ handle/316497/34045 [in Ukrainian].

3. Radkevych, A.V., Arutyunyan, I.A., Saikov, D.V. (2018). Optymizaciia organizaciinykh protsesiv budivelnoho vyrobnytstva yak formotvorcha skladova konkurentospromozhnosti pidryadnykh pidpryiemstv. Shliakhy pidvyshhennia efektyvnosti budivnytstva $v$ umovah formuvannia rynkovykh vidnosyn: zb. nauk. Pracz - Ways to increase the efficiency of construction in the formation of market relations: Coll. Science. wash. Vyp. 35. K.: Vyd-cztvo Lira-K. P. 64-73. [in Ukrainian].

4. Korotayeva, Yu.V. (2017). Formuvannia ta vykorystannia potencialu budivelnoi galuzi. Derzhava ta regiony. Seriia: Ekonomika ta pidpryiemnytsvo - State and regions. Series: Economics and Entrepreneurship. \# 3. P. 15-19. [in Ukrainian].

5. Pavlovski, H. (2017). Shhodo problem rozvytku diialnosti pidpryiemstv budivelnoyi sfery v Ukrayini. Mizhnarodnyi naukovyi zhurnal «Internauka» . \# 3(2). P. 124-135. [in Ukrainian].

6. Prodanova, L.V. (2016). Problemni aspekty rozvytku rynku budivelnoi haluzi Ukrainy. Ekonomichnyi visnyk Zaporizkoi derzhavnoi inzhenernoi akademii - Economic Bulletin of the Zaporizhzhia State Engineering Academy. Vyp. 6 (2). P. 57-61. [in Ukrainian].

7. Mykytiuk, P.P. (2015). Investytsiino-innovatsiinyi menedzhment [Investment and innovation management]: navch. posib. Ternopil : Ekonomichna dumka, 452 p. [in Ukrainian].

8. Keranchuk, T.L. (2011). Koncepciia vartisno-oriientovanogo upravlinnia pidpryiemstvom ta mozhlyvosti yiyi adaptaciii v Ukrayini. Finansy Ukrainy - Finance of Ukraine. \# 7. P. 104-114. [in Ukrainian].

9. Bubenko, O.P. (2012). Innovaciini skladovi pidvyshhennia efektyvnosti budivelnykh pidpryiemstv. BiznesInform - BusinessInform. \#12. P. 156-161. [in Ukrainian].

10. Kytaiski proekty 3d budynkiv. Retrieved from: https://tjournal.ru/53763-villascreated-using-3d-printers [in Ukrainian].

Статтю отримано 14 травня 2020 р.

Article received May 14, 2020 